\author{
M. Anello • R. Lupi - D. Spampinato - S. Piro • \\ M. Masini • U. Boggi • S. Del Prato • A. M. Rabuazzo • \\ F. Purrello • P. Marchetti
}

\title{
Functional and morphological alterations of mitochondria in pancreatic beta cells from type 2 diabetic patients
}

Received: 27 April 2004 / Accepted: 4 September 2004 / Published online: 15 January 2005

C) Springer-Verlag 2005

\begin{abstract}
Aims/hypothesis: Little information is available on the insulin release properties of pancreatic islets isolated from type 2 diabetic subjects. Since mitochondria represent the site where important metabolites that regulate insulin secretion are generated, we studied insulin release as well as mitochondrial function and morphology directly in pancreatic islets isolated from type 2 diabetic patients. Methods: Islets were prepared by collagenase digestion and density gradient purification, and insulin secretion in response to glucose and arginine was assessed by the batch incubation method. Adenine nucleotides, mitochondrial membrane potential, the expression of UCP-2, complex I and complex $\mathrm{V}$ of the respiratory chain, and nitrotyrosine levels were evaluated and correlated with insulin secretion. Results: Compared to control islets, diabetic islets showed reduced insulin secretion in response to glucose, and this defect was associated with lower ATP levels, a lower ATP/ADP ratio and impaired hyperpolarization of the mitochondrial membrane. Increased protein expression of UCP-2, complex I and complex V of the respiratory chain, and a higher level of nitrotyrosine were also found in type 2 diabetic islets. Morphology studies showed that control and diabetic beta cells had a similar number of mitochondria; however, mitochondrial density volume was significantly higher in type 2 diabetic beta cells. Conclusions/
\end{abstract}

\section{Anello - D. Spampinato - S. Piro - A. M. Rabuazzo · F. Purrello \\ Internal Medicine, Department of Internal and Specialistic Medicine, University of Catania, Ospedale Cannizzaro, Catania, Italy}

R. Lupi - M. Masini - U. Boggi - S. Del Prato · P. Marchetti Department of Endocrinology and Metabolism, Metabolic Unit, University of Pisa,

Pisa, Italy

F. Purrello $(\square)$

Clinica Medica, Ospedale Cannizzaro,

Via Messina 829,

95126 Catania, Italy

e-mail: fpurrello@virgilio.it

Tel.: +39-095-7262053

Fax: +39-095-7262582 interpretation: In pancreatic beta cells from type 2 diabetic subjects, the impaired secretory response to glucose is associated with a marked alteration of mitochondrial function and morphology. In particular, UCP-2 expression is increased (probably due to a condition of fuel overload), which leads to lower ATP, decreased ATP/ADP ratio, with consequent reduction of insulin release.

Keywords Adenine nucleotides - Insulin secretion Mitochondria $\cdot$ Type 2 diabetes $\cdot$ UCP-2

Abbreviations ADP: adenosine diphosphate - ATP: adenosine triphosphate - BMI: body mass index - BSA: bovine serum albumin - FCCP: carbonylcyanide $p$ trifluoromethoxyphenylhydrazone - KRB: krebs-Ringer bicarbonate solution $\cdot \Delta \Psi_{\mathrm{m}}$ : mitochondrial membrane potential - NEFA: non-esterified fatty acid $\cdot$ Rh123: rhodamine-123 - SI: stimulation index - TCA: trichloracetic acid - TMB: tetramethyl-benzidine - UCP-2: uncoupling protein-2

\section{Introduction}

Type 2 diabetes mellitus is a metabolic and vascular disease that has reached epidemic proportions, and represents a serious health concern. Its prevalence worldwide is set to increase from its present level of 150 million to 225 million by the end of the decade [1]. Moreover, its incidence is increasing at an alarming rate also in children and adolescents [2]. The long-term complications of this disease carry a crushing burden of morbidity and mortality, and most type 2 diabetic patients die prematurely from a cardiovascular event [3-5].

Type 2 diabetes is characterized by defective pancreatic beta cell insulin release in response to glucose and by impaired insulin action on its target tissues. The relative importance of the secretory defects has been recently outlined by several clinical observations. Insulin resistance alone is not sufficient to lead to type 2 diabetes in the absence of a beta cell defect [6-8]. Patients with impaired 
glucose tolerance or in the early stages of type 2 diabetes always present with defects of beta cell secretion [9]. Clinical diabetes develops only when the compensatory hypersecretion of insulin by the pancreatic beta cell declines [8]. Moreover, as demonstrated in the UKPDS study [10], type 2 diabetic patients are characterized by a progressive decline of insulin secretion that becomes more severe with the increasing duration of the disease.

Conceivably, a more direct assessment of the functional characteristics of the diabetic beta cell would represent a better tool for identification of alterations associated with impaired insulin secretion. However, little information is available on the insulin release properties of islets isolated from type 2 diabetic subjects. Pancreatic islets were studied from seven type 2 diabetic patients (obtained by intraoperative biopsy) [11]. The authors reported that despite a marked reduction of glucose-stimulated insulin secretion in vivo, a normal insulin release was induced by glucose from the isolated islets, suggesting that extrapancreatic factors influence beta cell reaction to glucose in type 2 diabetes. Another study investigated insulin secretion function in pancreatic islets from two type 2 diabetic organ donors, and found a marked decrease of insulin secretion during glucose stimulation, although the secretory response to a combination of leucine and glutamine was less severely affected [12]. In a recent report, islets from diabetic donors secreted less insulin and exhibited an elevated threshold for glucose-induced insulin release [13].

The altered insulin secretory pattern might depend on genetic and/or acquired abnormalities, including the negative influence of chronic high glucose [14-17] and/or high non-esterified fatty acids (NEFA) [18-21] plasma concentrations (gluco- or lipo-toxicity). In normal beta cells glucose regulates insulin release through its metabolism, and mitochondria represent the site where important metabolites that regulate insulin secretion are generated [22-24]. Several studies have focused the attention on the adenine nucleotides as regulators of insulin secretion. In particular, the increase of ATP/ADP ratio tightly associates to glucose-induced insulin granule release $[25,26]$. In addition to mitochondrial glucose oxidation, ATP synthesis and ATP/ADP ratio are regulated by uncoupling protein-2 (UCP-2) expression [27-30]. UCP-2 is a member of a family of proteins located in the mitochondrial inner membrane, which act as proton channels uncoupling mitochondrial oxidative phosphorylation. By this mechanism, energy is wasted through heat and cellular ATP synthesis is decreased [31].

The aim of this work was, therefore, to investigate insulin secretion and mitochondrial function and morphology in human islets from type 2 diabetic patients. We measured adenine nucleotides, mitochondrial membrane potential, the expression of UCP-2, complex I and complex V of the respiratory chain, nitrotyrosine levels, and correlated them with insulin secretion. Moreover, we studied mitochondrial ultrastructure. We found distinct differences between diabetic and non-diabetic subjects.

\section{Materials and methods}

Human islet preparation Pancreatic islets were prepared by collagenase digestion and density gradient purification, as previously reported $[32,33]$. All protocols were approved by the local Ethics Committee. For this study, islets were obtained from 11 non-diabetic human multiorgan donors (age $58 \pm 5.4$ years, BMI $24.6 \pm 1.4 \mathrm{~kg} / \mathrm{m}^{2}$, mean \pm SEM), and from seven type 2 diabetic patients (age $65 \pm 6$ years, BMI $27.4 \pm 2.2 \mathrm{~kg} / \mathrm{m}^{2}$, mean $\pm \mathrm{SEM}$ ). Mean duration of clinical diabetes was $5.6 \pm 0.6$ years; plasma glucose concentration, at the time of admission, was $273.3 \pm 38.5 \mathrm{mg} / \mathrm{dl}$. Four diabetic donors were treated with only diet restriction; two with sulphonylurea treatment; one with both sulphonylurea and metformin. Three diabetic subjects and three controls were also screened for GAD antibodies, which resulted negative. Digestion time was similar in control ( $38 \pm 3 \mathrm{~min})$ and diabetic $(36 \pm 4 \mathrm{~min})$ islet isolations. At the end of the isolation procedure, islets were resuspended in M199 culture medium (containing $5.5 \mathrm{mmol} / 1$ glucose), supplemented with $10 \%$ adult bovine serum, antibiotics (penicillin, $100 \mathrm{U} / \mathrm{ml}$; streptomycin, $100 \mu \mathrm{g} / \mathrm{ml}$; gentamicin, $50 \mu \mathrm{g} / \mathrm{ml}$; and amphotericin B, $0.25 \mu \mathrm{g} / \mathrm{ml})$, and cultured at $37^{\circ} \mathrm{C}$ in $5 \% \mathrm{CO}_{2}$.

Insulin secretion Insulin secretion studies were performed by the batch incubation technique as previously described $[33,34]$. Following a $45-\mathrm{min}$ period of incubation at $37^{\circ} \mathrm{C}$ in medium containing $3.3 \mathrm{mmol} / 1$ glucose, groups of approximately 30 islets of comparable size were kept at $37^{\circ} \mathrm{C}$ for $45 \mathrm{~min}$ in Krebs-Ringer bicarbonate solution (KRB), $0.5 \%$ albumin, $\mathrm{pH} 7.4$, containing $3.3 \mathrm{mmol} / 1$ glucose. At the end of this period, medium was completely removed, assayed to measure "basal" insulin secretion, and replaced with KRB containing either $16.7 \mathrm{mmol} / \mathrm{l}$ glucose, or 3.3 $\mathrm{mmol} / \mathrm{l}$ glucose plus $20 \mathrm{mmol} / \mathrm{l}$ arginine. After additional 45-min incubation, medium was removed, and insulin levels were measured to assess "stimulated" insulin release. Insulin secretion was expressed as absolute value, as percent of islet insulin content, and as stimulation index (SI), i.e. the ratio of stimulated over basal insulin secretion [35]. Insulin concentrations were measured by a commercially available immunoradiometric assay (Pantec Forniture Biomediche, Turin, Italy).

Adenine nucleotide measurement Adenine nucleotides were measured as previously reported [36]. Following islet incubation with 3.3 or $16.7 \mathrm{mmol} / \mathrm{l}$ glucose, the experiments were stopped by the addition of $0.125 \mathrm{ml}$ of trichloracetic acid (TCA) (Sigma, St. Louis, MO, USA). The extracts were frozen at $-80^{\circ} \mathrm{C}$ until the day of the assay, which started with an appropriate further dilution. ATP and ADP were assayed in triplicate by a luminometric method [37]. To measure total ATP+ADP, ADP was first converted into ATP. Samples, with known concentrations of ADP, without ATP, were run in parallel to check that the transformation was complete. ATP was measured by the addition of a reagent containing luciferase and luciferin (Sigma, St. Louis, MO, USA). The emitted light was measured in a luminometer (Junior LB 
9509-Berthold Technologies, Germany). To measure only ATP, the same previously described procedure was followed, except that in the first incubation step pyruvate kinase was lacking. ADP levels were then calculated by subtracting ATP from the total ATP+ADP. Blanks and ATP standards were run through the entire procedure, including the extraction steps.

Mitochondrial membrane potential $\left(\Delta \Psi_{m}\right) \Delta \Psi_{\mathrm{m}}$ was measured using rhodamine-123 (Rh123) (Sigma, St. Louis, MO, USA) as an indicator of mitochondrial membrane potential changes in an islet cell suspension under glucose stimulation $(16.7 \mathrm{mmol} / \mathrm{l})$. Cell were prepared from $\sim 3,000$ human pancreatic islets according to the method described before [16]. Briefly, islets were transferred to $\mathrm{Ca}^{2+}$-free $\mathrm{KRB}$ at $30^{\circ} \mathrm{C}$ with $1 \mathrm{mmol} / \mathrm{l}$ EGTA, $16.5 \mu \mathrm{g} / \mathrm{ml}$ trypsin, $2 \mu \mathrm{g} / \mathrm{ml}$ DNAse (Boehringer, Mannheim, Germany), and were gently resuspended with a Pasteur pipette. Cell dissociation was monitored, by observing the suspension with a microscope. Single cell suspension was then cultured in M199 medium overnight at $37^{\circ} \mathrm{C}$ in a $95 \% \mathrm{O}_{2} / 5 \% \mathrm{CO}_{2}$ atmosphere. Islet cells were then loaded in KRB buffer containing $3.3 \mathrm{mmol} / 1$ glucose and $10 \mu \mathrm{g} / \mathrm{ml} \mathrm{Rh} 123$ for 30 min at $37^{\circ} \mathrm{C}$. Cells were resuspended in the same buffer without Rh123 and transferred to a fluorometer (Hitachi F-2000) cuvette, and the fluorescence excited at $490 \mathrm{~nm}$ was measured at $530 \mathrm{~nm}$, at $37^{\circ} \mathrm{C}$ with gentle stirring. Results are expressed as percentage of basal fluorescence (at $3.3 \mathrm{mmol} / \mathrm{l}$ glucose).

Determination of nitrotyrosine Nitrotyrosine concentrations were determined in islet cell lysates by an ELISA method as reported [38]. Briefly, 96-well plates were coated with $200 \mu \mathrm{l}$ of standard curve samples $(0.166-15$ $\mathrm{nmol} / \mathrm{l})$ and $1 \mu \mathrm{g} / \mu \mathrm{l}$ of lysate $(65 \mu \mathrm{l} / \mathrm{well})$ in $0.1 \mathrm{~mol} / \mathrm{l}$ carbonate-bicarbonate buffer $(135 \mu \mathrm{l}), \mathrm{pH} 9.6$, overnight at $4{ }^{\circ} \mathrm{C}$. Afterwards, non-specific binding sites were blocked with $1 \%$ BSA in PBS-T (PBS plus $0.05 \%$ Tween 20), for $1 \mathrm{~h}$ at $37^{\circ} \mathrm{C}$ and washed with PBS-T. Plates were then incubated with purified monoclonal anti-nitrotyrosine mouse $\operatorname{IgG}$ for $1 \mathrm{~h}$ at $37^{\circ} \mathrm{C}$, washed and incubated with peroxidase-conjugated goat anti-mouse IgG secondary antibody for $45 \mathrm{~min}$ at $37^{\circ} \mathrm{C}$. Peroxidase reaction product was generated using tetramethyl-benzidine (TMB) Microwell Peroxidase Substrate (Sigma, St. Louis, MO, USA). Plates were then incubated 5-10 $\mathrm{min}$ at room temperature and the reaction was stopped with $0.5 \mathrm{~mol} / 1 \mathrm{H}_{2} \mathrm{SO}_{4}$, and optical density read at $492 \mathrm{~nm}$ in a microplate reader.

Western blot analysis Uncoupling protein-2 (UCP-2), NADH-ubiquinone oxidoreductase (complex I), $\mathrm{F}_{1}$-ATPsynthase (complex V) and SREBP-1c protein levels were measured by western blot analysis. Briefly, groups of $\sim 300$ human islets were homogenized by sonication in SDSPAGE sample buffer and equivalent amounts of proteins were separated on SDS-polyacrylamide gel (Mini-Protean, Bio-Rad, Hercules, CA, USA) and electrophoretically transferred onto nitrocellulose membrane (Amersham Pharmacia Biotech, England). Blotting efficiency as well as the posi- tion of protein standards was assessed by Ponceau staining. After blocking, the membranes were incubated with a rabbit polyclonal anti-UCP-2 antibody (Alpha Diagnostic International, San Antonio, TX, USA) at 1:2,000 dilution in blocking solution, or with a monoclonal anti-NADH-ubiquinone oxidoreductase (Molecular Probes, Eugene, OR, USA) 1:1,000, or with a goat polyclonal anti-F F $_{1}$ ATPsynthase antibody (Santa Cruz Biotechnology, Inc., USA) $1: 1,000$, or with a monoclonal anti-SREBP-1c (2A4) antibody (Santa Cruz Biotechnology, Inc., USA) 1:1,000 dilution at $4^{\circ} \mathrm{C}$, overnight. The membranes were then blotted with an anti-rabbit $(1: 2,000)$ or an anti-mouse $(1: 5,000) \operatorname{IgG}$ peroxidase-linked whole antibody (Pierce, Rockford, IL, USA), or with a monoclonal anti-goat IgG peroxidase conjugate (Sigma, St. Louis, MO, USA) diluted 1:10,000, $1 \mathrm{~h}$ at room temperature. Peroxidase activity was detected using ECL (Amersham Pharmacia Biotech, England).

Electron microscopy evaluation Electron microscopy studies were performed as previously described [33, 34, 39]. Pancreatic samples were fixed with $2.5 \%$ glutaraldehyde in $0.1 \mathrm{~mol} / 1 \mathrm{l}$ cacodylate buffer, $\mathrm{pH} 7.4$ for $1 \mathrm{~h}$ at $4^{\circ} \mathrm{C}$. After rinsing in cacodylate buffer, the tissue was postfixed in $1 \%$ cacodylate buffered osmium tetroxide for $2 \mathrm{~h}$ at room temperature, then dehydrated in a graded series of ethanol, briefly transferred to propylene oxide and embedded in Epon-Araldite. Ultrathin sections (60-80 nm thick) were cut with a diamond knife, placed on formvar-carbon coated copper grids (200 mesh), and stained with uranyl acetate and lead citrate.

Statistical analysis Data are presented as the mean \pm SEM. Statistical significance was assessed by Student's $t$-test, or one-way ANOVA followed by Newman-Keul's test when more than two groups were compared. $p$ Values of less than 0.05 were considered statistically significant.

\section{Results}

Insulin secretion As shown in Table 1, glucose $(16.7 \mathrm{mmol} /$ 1)-induced insulin release was significantly lower from the diabetic as compared to non-diabetic islets. Since islets from diabetic subjects contained $34 \%$ less insulin than control islets $(78 \pm 4.7$ vs. $118 \pm 4.2 \mu \mathrm{U} /$ islet, $p<0.01)$, we also expressed our data as percent of islet insulin content (Table 2). Using this method, glucose-induced insulin secretion was again lower in diabetic islets. Using both methods, arginine-stimulated insulin release did not differ significantly between the two groups (Tables 1 and 2). These experiments, therefore, showed a selective defect of type 2 diabetes beta cells to release insulin in response to glucose stimulation.

Measurements of adenine nucleotides content The ATPto-ADP ratio, also in human islets, plays a critical role in glucose-induced beta cell insulin secretion [25]. Therefore, we measured adenine nucleotide content in pancreatic islets from diabetic and non-diabetic subjects, in 
Table 1 Insulin secretion ( $\mu \mathrm{U} /$ islet/45 $\mathrm{min})$, under glucose $(\mathrm{Glu})$ or arginine (Arg) stimulation in pancreatic islets from control and type 2 diabetic subjects

\begin{tabular}{lllccc}
\hline & Glu $(3.3 \mathrm{mmol} / \mathrm{l})$ & Glu $(16.7 \mathrm{mmol} / \mathrm{l})$ & SI-Glu & Arg $(20 \mathrm{mmol} / \mathrm{l})$ & SI-Arg \\
\hline Controls $(n=11)$ & $2.34 \pm 0.17$ & $5.63 \pm 0.45^{\mathrm{a}}$ & $2.5 \pm 0.2$ & $5.71 \pm 0.54^{\mathrm{a}}$ & $2.4 \pm 0.26$ \\
Type 2 diabetes $(n=7)$ & $2.18 \pm 0.26$ & $2.57 \pm 0.32^{\mathrm{b}}$ & $1.26 \pm 0.19^{\mathrm{b}}$ & $4.3 \pm 0.55^{\mathrm{a}}$ & $2.0 \pm 0.14$ \\
\hline
\end{tabular}

Data are means \pm SEM

${ }_{p}^{\mathrm{a}}<0.05$ or less vs. $3.3 \mathrm{mmol} / \mathrm{l}$ glucose

${ }^{\mathrm{b}} p<0.05$ or less vs. controls

SI-Glu Ratio of glucose-stimulated over basal insulin secretion, SI-Arg ratio of arginine-stimulated over basal insulin secretion

the presence of basal $(3.3 \mathrm{mmol} / \mathrm{l})$ and stimulating $(16.7$ $\mathrm{mmol} / \mathrm{l}$ ) glucose concentrations (Fig. 1). Islets from diabetic subjects had a higher ATP content in basal condition $(14.22 \pm 1.58$ vs. $9.82 \pm 0.31 \mathrm{pmol} / \mu \mathrm{g}$ of islet DNA, $n=30$ replicates from type 2 diabetic subjects vs. 45 from controls, $p<0.01$ ) and a higher ATP/ADP ratio (Fig. 1). In response to glucose stimulation, ATP levels significantly increased in control islets (from 9.82 \pm 0.31 to $16.11 \pm 0.27 \mathrm{pmol} / \mu \mathrm{g}$ of islet DNA, $p<0.001$, but not in diabetic islets (from $14.22 \pm 1.58$ to $13.22 \pm 1.31 \mathrm{pmol} / \mu \mathrm{g}$ of islet DNA), the latter being significantly lower than control $(p=0.01)$. As a consequence, in response to glucose stimulation, the ATP/ADP ratio was lower in diabetic subjects than in control group (15.85 \pm 0.98 vs. $24.14 \pm$ 1.77, $p<0.001$ ) (Fig. 1).

Mitochondrial membrane potential measurements Since the energy to drive ATP formation is provided by a proton gradient across the inner mitochondrial membrane, we measured glucose-induced changes in mitochondrial membrane potential $\left(\Delta \Psi_{\mathrm{m}}\right)$ [40]. The Rh123 fluorescence was recorded in a cell suspension from islets of diabetic and non-diabetic subjects, as indicated on a graph section. In control cells when glucose concentration was increased to $16.7 \mathrm{mmol} / 1$, fluorescence decreased $(-9.6 \pm 0.1 \%$, mean \pm SEM, $n=5)$, indicating the glucose-induced hyperpolarization of $\Delta \Psi_{\mathrm{m}}$ (Fig. 2a). Cells from diabetic subjects showed a decreased hyperpolarization of $\Delta \Psi_{\mathrm{m}}$ when glucose was raised to $16.7 \mathrm{mmol} / 1(-6.5 \pm 0.54 \%$, mean $\pm \mathrm{SEM}$, $n=4, p<0.001$ ) (Fig. 2b). The addition of the uncoupler carbonylcyanide $p$-trifluoromethoxyphenylhydrazone (FCCP) $1 \mu \mathrm{mol} / \mathrm{l}$ readily depolarised $\Delta \Psi_{\mathrm{m}}$ in both the experimental conditions (Fig. 2).

Table 2 Insulin secretion as percentage of islet insulin content/45 min, under glucose (Glu) or arginine (Arg) stimulation in pancreatic islets from control and type 2 diabetic subjects

\begin{tabular}{lcll}
\hline & $\begin{array}{l}\text { Glu (3.3 } \\
\mathrm{mmol} / 1)\end{array}$ & $\begin{array}{l}\text { Glu (16.7 } \\
\mathrm{mmol} / 1)\end{array}$ & $\begin{array}{l}\text { Arg (20 } \\
\mathrm{mmol} / \mathrm{l})\end{array}$ \\
\hline Controls $(n=11)$ & $1.98 \pm 0.14$ & $4.77 \pm 0.38 \mathrm{a}^{\mathrm{b}}$ & $4.82 \pm 0.46 \mathrm{a}^{\mathrm{b}}$ \\
$\begin{array}{l}\text { Type 2 diabetes } \\
(n=7)\end{array}$ & $2.8 \pm 0.34 \mathrm{~b}^{\mathrm{a}}$ & $3.29 \pm 0.41 \mathrm{~b}^{\mathrm{a}}$ & $5.52 \pm 0.71 \mathrm{a}^{\mathrm{b}}$ \\
\hline
\end{tabular}

Data are means \pm SEM

${ }_{p} p<0.05$ or less vs. $3.3 \mathrm{mmol} / 1$ glucose

${ }^{\mathrm{b}} p<0.05$ or less vs. controls
Mitochondrial protein expression To analyse the expression of mitochondrial proteins involved in pancreatic beta cell energy production, we studied, by Western blot, the levels of the uncoupling protein-2 (UCP-2), and of complex I (NADH-ubiquinone oxidoreductase) and complex $\mathrm{V}$ ( $\mathrm{F}_{1}$-ATP synthase) of the respiratory chain. We found that UCP-2 protein levels were significantly increased in islets from diabetic subjects $(+24 \pm 6 \%$, mean $\pm \mathrm{SEM}, n=4$, $p<0.01$ ) compared to control subjects (Fig. 3). We also
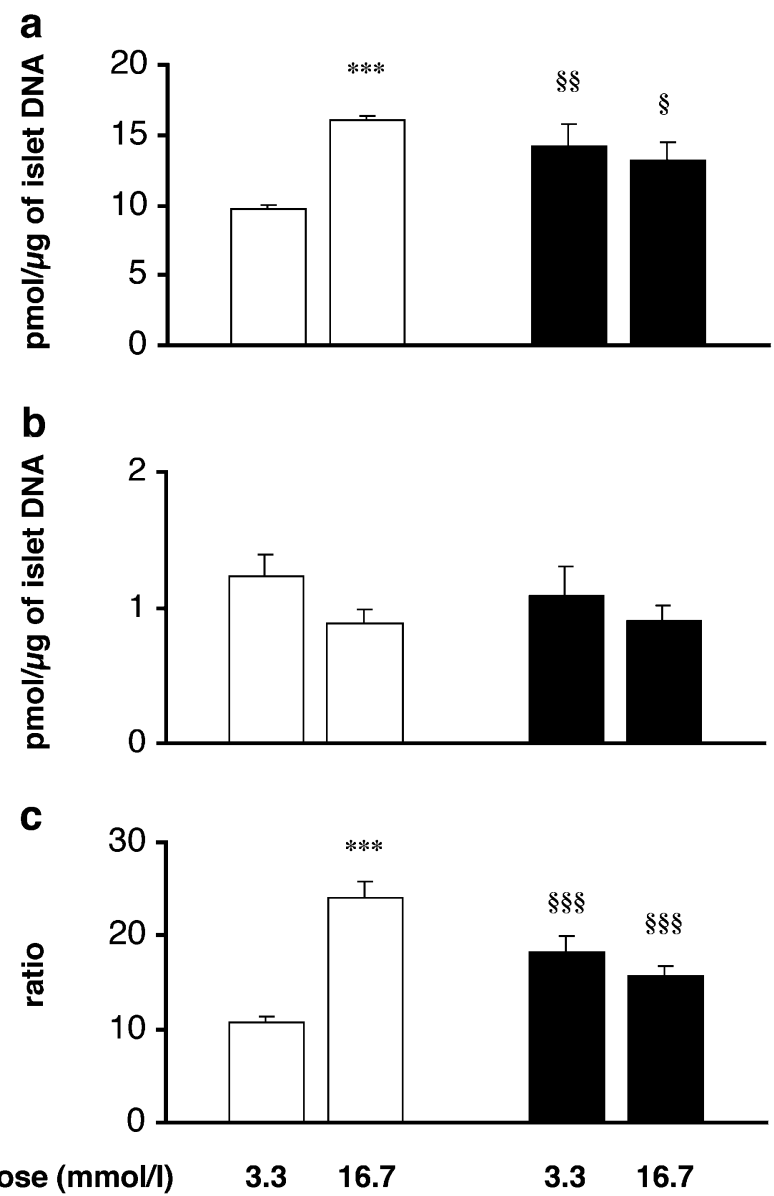

\section{Glucose (mmol/l)}

Fig. 1 Adenine nucleotide concentrations (ATP in panel a, ADP in panel b, ATP-to-ADP ratio in panel c). Batches of five islets from control (white bar) or type 2 diabetic subjects (black bar) were incubated in $1 \mathrm{ml}$ of KRB medium containing the indicated glucose concentrations. At the end of incubation $(1 \mathrm{~h})$, islets were processed for measuring adenine nucleotide content. Results are means \pm SEM of 45 replicates from five control and 30 replicates from four type 2 diabetic subjects. ${ }^{* * *} p<0.001$ vs $3.3 \mathrm{mmol} / 1$ glucose, ${ }^{\S} p<0.05$ vs control, ${ }^{\S \S} p<0.01$ vs control, ${ }^{\S \S} p<0.001$ vs control 


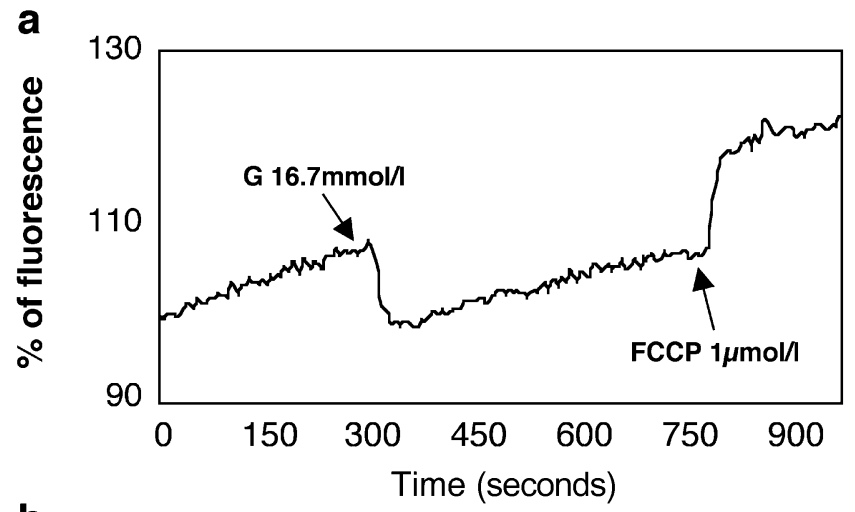

b

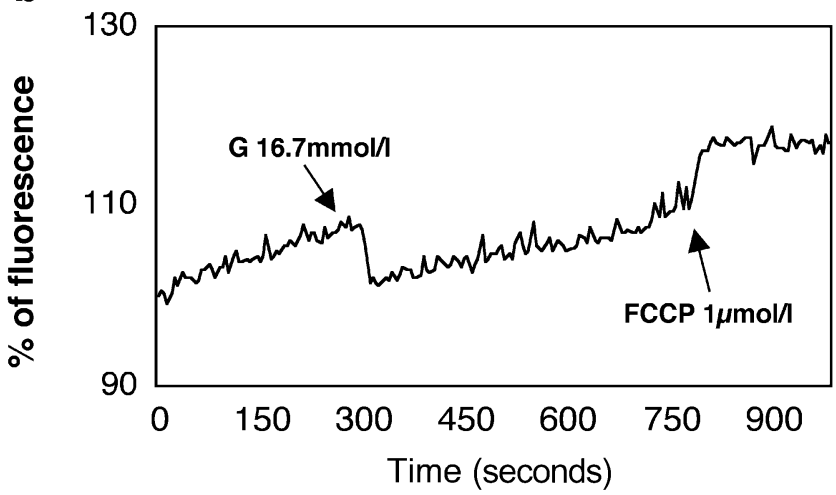

C

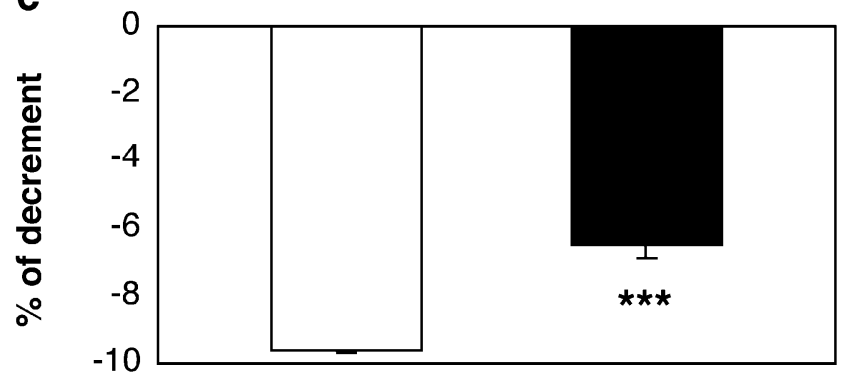

Fig. 2 Glucose-induced mitochondrial membrane potential changes $\left(\Delta \Psi_{\mathrm{m}}\right)$. Glucose $(16.7 \mathrm{mmol} / \mathrm{l})$ induced hyperpolarisation in human pancreatic islet cell suspension, from non-diabetic (a) and diabetic subjects (b). The depolarizing effect of the protonophore FCCP at the end of each trace is used as control of the $\Delta \Psi_{\mathrm{m}}$ integrity. Results are percentage of basal fluorescence (at $3.3 \mathrm{mmol} / 1$ glucose). The traces represent mean of five separate experiments for control and four separate experiments for diabetic subjects. c Summary of $\Delta \Psi_{\mathrm{m}}$ changes over the basal level in glucose-induced hyperpolarization of mitochondrial membrane potential in control (white bar) and in type 2 diabetic subjects (black bar). Results are percentage of decrement under basal fluorescence (at $3.3 \mathrm{mmol} / 1$ glucose). ${ }^{* * *} p<0.001$

found that protein expression of both complex I and V of the respiratory chain were increased in islets from diabetic subjects $(+14 \pm 4.5 \%$ and $+31 \pm 13 \%, n=4, p<0.01)$ compared to control (Fig. 3). In order to elucidate if upregulation of UCP-2 was due to a higher expression of SREBP-1c, we also measured the levels of this latter protein and found no differences between diabetic and control groups (Fig. 4).

Nitrotyrosine levels Respiratory chain activity leads to the formation of reactive oxygen species. To investigate if the

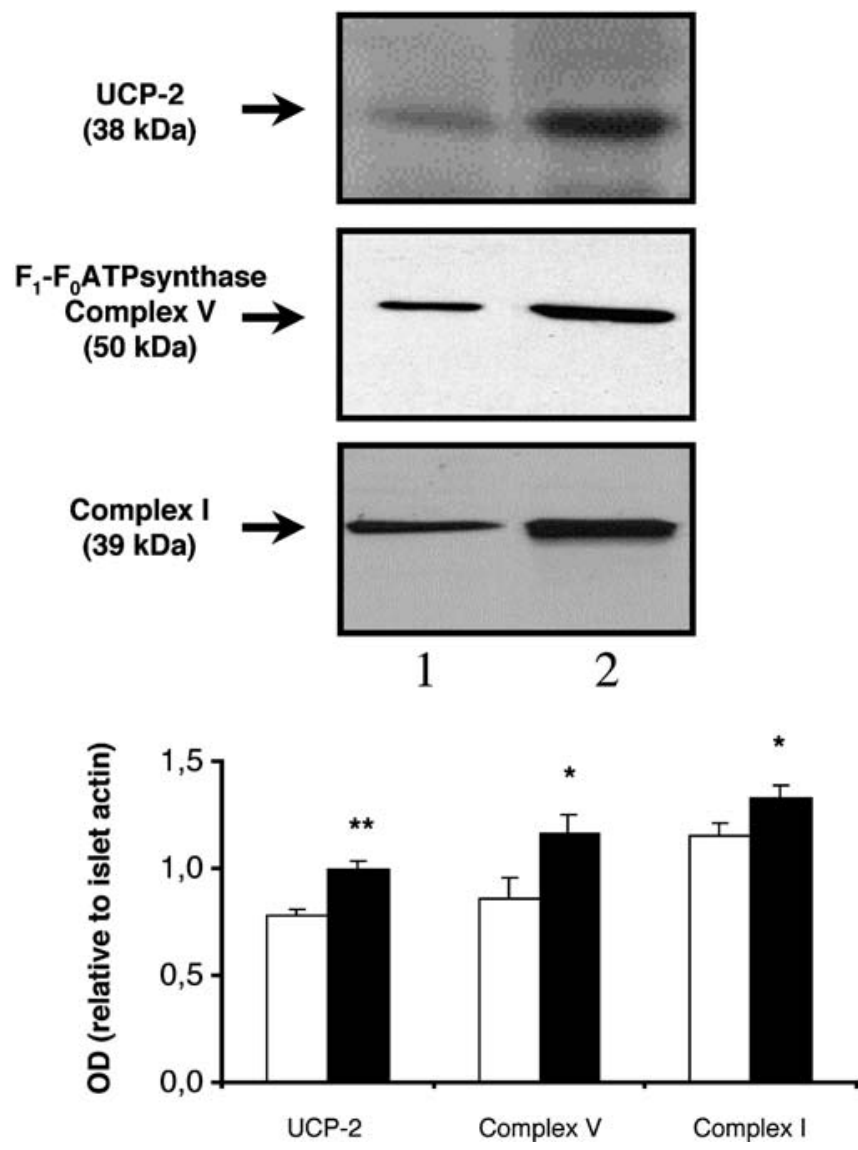

Fig. 3 A representative Western blot for UCP-2, $\mathrm{F}_{1}-\mathrm{F}_{0}$ ATPsynthase (complex V) and NADH-ubiquinol oxidoreductase (complex I) in human pancreatic islets from non-diabetic (lane 1) and type 2 diabetic subjects (lane 2). Results are mean \pm SEM of scanning densitometry relative to islet actin of four separate western blots. ${ }^{*} p<0.05,{ }^{*} p<0.01$ vs. non-diabetic subjects

increased levels of the respiratory chain enzymes in islets from diabetic subjects might lead to increased oxidative stress, we measured nitrotyrosine levels. This compound derives from the reaction of superoxide and nitric oxide, and is considered a reliable marker of oxidative stress. Nitrotyrosine levels were respectively $7.2 \pm 0.4$ and $9.9 \pm 0.4$ $\mathrm{nmol} / \mathrm{l}$ in control islets $(n=7)$ and type 2 diabetes islets $(n=6)(p<0.05)$.

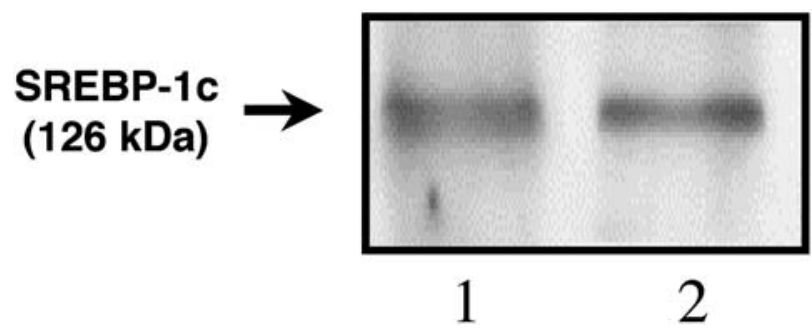

Fig. 4 Representative western blot for SREBP-1c in human pancreatic islets from non-diabetic (lane 1) and type 2 diabetic subjects (lane 2) 
Fig. 5 Mitochondrial structure in pancreatic islets beta cell from normal (a) and diabetic subjects (b). White arrow indicates mitochondria. Hashed arrow indicates insulin granules. Mitochondrial density volume was significantly higher in beta cells from type 2 diabetic subjects compared to control subjects $(4.7 \pm 0.3 \mathrm{ml} \%$ vs. $3.1 \pm 0.4$ $\mathrm{ml} \%, p<0.01)$. Magnification $\times 16,000$
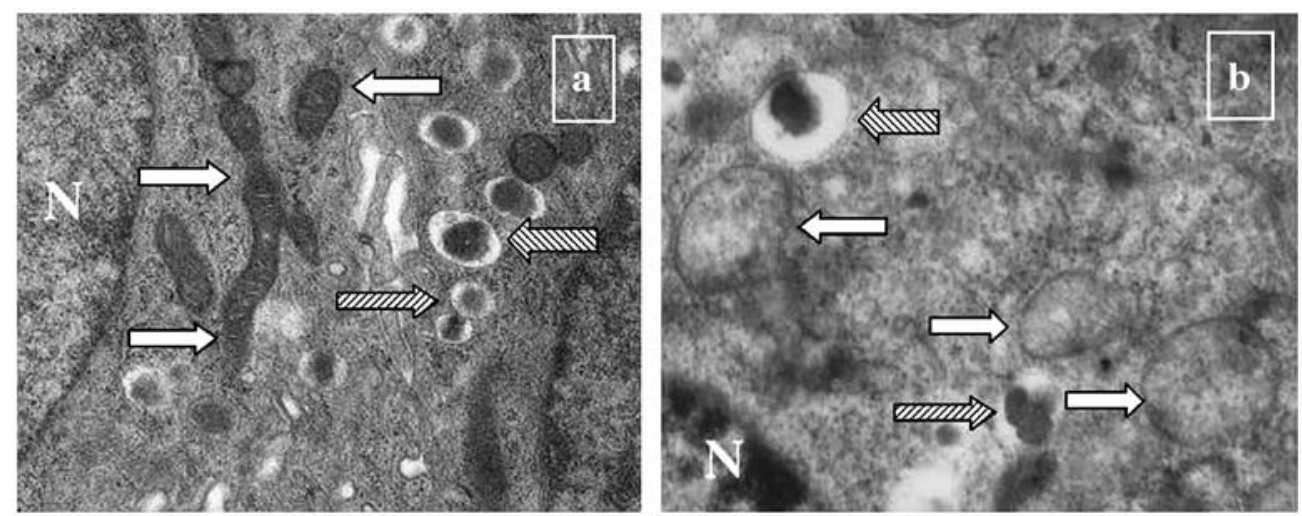

Electron microscopy studies Endocrine cellular composition from pancreas preparation was $69 \pm 4,22 \pm 4$ and $9 \pm 2 \%$ in controls and $61 \pm 3,25 \pm 7$ and $14 \pm 5 \%$ in diabetic patients (mean \pm SEM, $n=4$ ), for beta, alpha and delta cells, respectively. Cell viability, measured as trypan blue exclusion, was higher than $90 \%$ in both controls $(n=5)$ and diabetic patients $(n=3)$. As shown in Fig. 5, mitochondria in type 2 diabetes beta cells appeared round-shaped and hypertrophic. Compared to control beta cells $(n=112$ cells, from three pancreases), type 2 diabetes beta cells $(n=108$ cells, from three pancreases) had a similar number of mitochondria ( $12.0 \pm 0.9$ vs. $12.4 \pm 0.6$ per microscopy field). However, the mitochondrial density volume from type 2 diabetic subjects was significantly $(p<0.01)$ higher $(4.7$ $\pm 0.3 \mathrm{ml} \%)$ than control beta cells $(3.1 \pm 0.4 \mathrm{ml} \%)$.

\section{Discussion}

In islets isolated from the pancreas of seven multiorgan donors who were affected by type 2 diabetes, we observed a clearly reduced insulin release in response to glucose, whereas the secretion of the hormone during stimulation with the non-fuel secretagogue arginine was only slightly affected. In order to investigate the basis of this selective defect, since mitochondrial metabolism, and the subsequent rise of ATP and of ATP/ADP ratio plays a central role in glucose-induced insulin release, we measured several key steps of the mitochondrial events that lead to ATP synthesis and correlated them with insulin secretion. The energy for ATP production is provided by oxidation of reducing equivalents via the electron-transport chain. The enzyme complexes I to $\mathrm{V}$ are located at the inner mitochondrial membrane and the flux of electrons along the respiratory chain establishes the proton gradient, which generates the membrane potential. Glucose stimulation results in the transfer of reducing equivalents to the respiratory chain, leading to hyperpolarization of the mitochondrial membrane $\left(\Delta \Psi_{\mathrm{m}}\right)$ and generation of ATP. In islets from diabetic subjects we found that glucose-induced hyperpolarization of the mitochondrial membrane was reduced. We also found that ATP levels were lower, at high glucose, and the ATP/ADP ratio was blunted, in response to glucose stimulation. These defects could conceivably be due to a reduced electron flux through the res- piratory chain, or to an over-expression of proteins (such as UCP-2) that tends to diminish the proton gradient generated by the respiratory chain. To test the first possibility we measured the protein expression of complex I and complex $\mathrm{V}$ of the respiratory chain and we found an increased expression that makes this hypothesis unlikely. To test the second possibility, we measured the protein expression of UCP-2, and we found, indeed, an increased expression of this protein. UCP-2 is a member of a family of proteins located in the mitochondrial inner membrane, which uncouples mitochondrial oxidative phosphorylation. By this mechanism, energy is wasted through heat and cellular ATP synthesis is decreased. UCP-2 protein expression could be activated by an increased formation of reactive oxygen species [41]. In agreement with this interpretation, in our model we found increased levels of nitrotyrosine (a marker of oxidative stress) in diabetic islets. According to these data, therefore, it is possible to suppose that in beta cells from diabetic patients the increased expression of UCP-2 is responsible of the reduced hyperpolarization of the mitochondrial membrane, lower ATP levels, ATP/ADP ratio, and eventually, of the reduced insulin release in response to glucose.

This sequence of events is coherent with several data obtained in vitro or in animal models, and recently put in perspective [42]. Increased UCP-2 levels in beta cells are associated with decreased insulin secretion [43, 44], and UCP-2 overexpression in rat pancreatic islets has been shown to inhibit glucose-stimulated insulin secretion by decreasing ATP formation [45]. Moreover, in rodent pancreatic islets chronically exposed to high glucose or NEFA glucose-induced impairment of insulin secretion is associated with altered mitochondrial function, including overexpression of the UCP-2 protein and a consequent decrease of ATP production [46]. In islets from hyperglycaemic $90 \%$ pancreatectomized rats [47] or in human islets exposed to high glucose [48], UCP-2 mRNA or protein expression was increased, in accordance with a decrease of glucose-induced insulin release. In a tumoral beta cell line, chronic exposure to high NEFA both reduced insulin secretion and increased UCP-2 levels by regulating glucose-induced ATP formation $[49,50]$. In other reports, UCP-2 overexpression by enhancing ATP/ADP ratio restores insulin secretion in islets from ZDF rat [51]. 
Further support to the concept that mitochondria in the diabetic beta cell are in an altered state comes from the morphological studies we performed. In fact, by electron microscopy examination, we found that the density volume of these organelles was significantly higher in type 2 diabetes beta cells than in control cells. Mitochondria undergo structural changes that parallel their functional state in both physiological as well as pathological conditions [52], and their enlargement, which can be induced by various pathological conditions, can be classified into two categories: the swelling and the formation of megamitochondria [53]. Both situations are considered to be adaptive processes at the subcellular level to unfavourable environments. For example, it has been demonstrated that when cells are exposed to excess amount of free radicals, the mitochondria become enlarged decreasing the rate of oxygen consumption and reducing ROS production [54]. These mechanisms are likely to play a role also in diabetes and in beta cell function. Indeed, evidence has been recently reported of swelling of mitochondria in sural nerve biopsies from patients with diabetic neuropathy [55]. In addition, loss of glucose-stimulated insulin secretion from isolated rat islets was associated with mitochondrial enlargement [56]. Finally, we have shown that exposure of human pancreatic islets to cytotoxic cytokines induces functional and survival beta cell damage, which is accompanied by mitochondrial swelling and enlargement $[57,58]$.

We observed a selective secretory defect in response to glucose, whereas the secretion of the hormone during stimulation with the non-fuel secretagogue arginine was only slightly affected, demonstrating an intrinsic and selective functional defect of beta cell function in type 2 diabetes. It is noteworthy that arginine-induced insulin release is largely independent on ATP synthesis, since this amino acid directly affects beta cell membrane potential and ion flux.

The present data, the first to our knowledge, indicate that in pancreatic beta cells from type 2 diabetic subjects, the impaired secretory response to glucose is associated with a marked impairment of mitochondrial function. The presence of excessive fuel availability increases substrate influx through the metabolic mitochondria pathways, leading to the generation of large amounts of high-energy metabolites and reactive oxygen species. Our novel results suggest that in the presence of such a situation, pancreatic beta cell UCP-2 expression is increased in humans, which leads to a lower ATP level and reduced ATP/ADP ratio in response to glucose, with consequent impairment of insulin release. A better understanding of these mechanisms, and the discovering of specific molecular targets would greatly enhance our clinical efficacy in preserving beta cell function in type 2 diabetic patients.

\section{References}

1. King H, Aubert RE, Herman WH (1998) Global burden of diabetes, 1995-2025: prevalence, numerical estimates, and projections. Diabetes Care 21:1414-1431
2. American Diabetes Association (2000) Type 2 diabetes in children and adolescents (consensus statement). Diabetes Care 23:381-389

3. Adler AI, Boyko EJ, Ahroni JH, Smith DG (1999) Hyperglycemia and hyperinsulinemia at diagnosis of diabetes and their association with cardiovascular disease in the United Kingdom Prospective Diabetes Study (UKPDS 47). Am Heart J 138: S353-S359

4. Adler AI, Stratton IM, Neil HA et al (2000) Association of systolic blood pressure with macrovascular and microvascular complications of type 2 diabetes (UKPDS 36): prospective observational study. BMJ 321:412-419

5. U.K. Prospective Diabetes Study Group (1998) Tight blood pressure control and risk of macrovascular and microvascular complications in type 2 diabetes (UKPDS 38). BMJ 317:703713

6. Polonsky KS, Sturis J, Bell G (1996) Non-insulin-dependent diabetes mellitus: a genetically programmed failure of the beta cell to compensate for insulin resistance. N Engl J Med 334:777_ 783

7. Weyer C, Bogardus C, Mott DM, Pratley RE (1999) The natural history of insulin secretory dysfunction and insulin resistance in the pathogenesis of type 2 diabetes mellitus. J Clin Invest 104:787-794

8. DeFronzo RA, Bonadonna RC, Ferrannini E (1992) Pathogenesis of NIDDM. A balanced overview. Diabetes Care 15:318 368

9. Ferrannini E, Gastaldelli A, Miyazaki Y et al (2003) Predominant role of reduced beta-cell sensitivity to glucose over insulin resistance in impaired glucose tolerance. Diabetologia 46:1211-1219

10. UK Prospective Diabetes Study (UKPDS) Group (1998) Intensive blood-glucose control with sulphonylureas or insulin compared with conventional treatment and risk of complications in patients with type 2 diabetes (UKPDS 33). Lancet 352:837-853

11. Lohmann D, Jahr H, Verlohren HJ et al (1980) Insulin secretion in maturity-onset-diabetes. Function of isolated islets. Horm Metab Res 12:349-353

12. Fernandez-Alvarez J, Conget I, Rasschaert J, Sener A, Gomis R, Malaisse WJ (1994) Enzymatic, metabolic and secretory patterns in human islets of type 2 (non-insulin-dependent) diabetic patients. Diabetologia 37:177-181

13. Deng S, Vatamaniuk M, Huang X et al (2004) Structural and functional abnormalities in the islets isolated from type 2 diabetic subjects. Diabetes 53:624-632

14. Grodsky GM, Bolaffi JL (1992) Desensitization of the insulinsecreting beta cell. J Cell Biochem 48:3-11

15. Leahy JL, Bonner-Weir S, Weir GC (1992) Beta-cell dysfunction induced by chronic hyperglycemia. Current ideas on mechanism of impaired glucose-induced insulin secretion. Diabetes Care 15:442-455

16. Purrello F, Vetri M, Gatta C, Gullo D, Vigneri R (1989) Effects of high glucose on insulin secretion by isolated rat islets and purified beta-cells and possible role of glycosylation. Diabetes 38:1417-1422

17. Robertson RP, Harmon J, Tran PO, Poitout V (2004) Beta-cell glucose toxicity, lipotoxicity, and chronic oxidative stress in type 2 diabetes. Diabetes 53 (Suppl 1):S119-S124

18. Kashyap S, Belfort R, Gastaldelli A et al (2003) A sustained increase in plasma free fatty acids impairs insulin secretion in nondiabetic subjects genetically predisposed to develop type 2 diabetes. Diabetes 52:2461-2474

19. Unger RH, Zhou YT (2001) Lipotoxicity of beta-cells in obesity and in other causes of fatty acid spillover. Diabetes 50 (Suppl 1):S118-S121

20. Wyne KL (2003) Free fatty acids and type 2 diabetes mellitus. Am J Med 115 (Suppl 8A):29S-36S

21. Poitout V, Robertson RP (2002) Secondary beta-cell failure in type 2 diabetes: a convergence of glucotoxicity and lipotoxicity. Endocrinology 143:339-342 
22. Maechler P (2002) Mitochondria as the conductor of metabolic signals for insulin exocytosis in pancreatic beta-cells. Cell Mol Life Sci 59:1803-1818

23. Wollheim CB, Maechler P (2002) Beta-cell mitochondria and insulin secretion: messenger role of nucleotides and metabolites. Diabetes 51 (Suppl 1):S37-S42

24. Maechler P, Wollheim CB (2001) Mitochondrial function in normal and diabetic beta-cells. Nature 13:807-812

25. Detimary P, Dejonghe S, Ling Z, Pipeleers D, Schuit F, Henquin JC (1998) The changes in adenine nucleotides measured in glucose-stimulated rodent islets occur in beta cells but not in alpha cells and are also observed in human islets. J Biol Chem 273:33905-33908

26. Henquin JC (2000) Triggering and amplifying pathways of regulation of insulin secretion by glucose. Diabetes 49:17511760

27. Chan CB, Saleh MC, Koshkin V, Wheeler MB (2004) Uncoupling protein 2 and islet function. Diabetes 53 (Suppl 1): S136-S142

28. Rousset S, Alves-Guerra MC, Mozo J et al (2004) The biology of mitochondrial uncoupling proteins. Diabetes 53 (Suppl 1): S130-S135

29. Saleh MC, Wheeler MB, Chan CB (2002) Uncoupling protein2: evidence for its function as a metabolic regulator. Diabetologia 45:174-187

30. Zhang CY, Baffy G, Perret P et al (2001) Uncoupling protein-2 negatively regulates insulin secretion and is a major link between obesity, beta cell dysfunction, and type 2 diabetes. Cell 15:745-755

31. Chan CB, De Leo D, Joseph JW et al (2001) Increased uncoupling protein-2 levels in beta-cells are associated with impaired glucose-stimulated insulin secretion: mechanism of action. Diabetes 50:1302-1310

32. Marchetti P, Dotta F, Ling Z et al (2000) Function of pancreatic islets isolated from Type 1 diabetic patient. Diabetes Care 23:701-703

33. Lupi R, Dotta F, Marselli L et al (2002) Prolonged exposure to free fatty acids has cytostatic and pro-apoptotic effects on human pancreatic islets. Evidence that $\beta$-cell death is caspasemediated, partially dependent on ceramide pathway, and Bcl-2 regulated. Diabetes 51:1437-1442

34. Marchetti P, Lupi R, Federici M et al (2002) Insulin secretory function is impaired in isolated human islets carrying the Gly (972) $\rightarrow$ Arg IRS-1 polymorphism. Diabetes 51:1419-1424

35. Gatto C, Callegari M, Folin M et al (2003) Effects of cryopreservation and coculture with pancreatic ductal epithelial cells on insulin secretion from human pancreatic islets. Int J Mol Med $12: 851-854$

36. Anello M, Ucciardello V, Piro S et al (2001) Chronic exposure to high leucine impairs glucose-induced insulin release by lowering the ATP/ADP ratio. Am J Physiol Endocrinol Metab 281:E1082-E1087

37. Hampp R (1986) Luminometric method. In: Bergmeyer HU (ed) Methods of enzymatic analysis. Verlagsgesellschaft, Weinheim, Germany, pp 370-379

38. Quagliaro L, Piconi L, Assaloni R, Martinelli L, Motz E, Ceriello A (2003) Intermittent high glucose enhances apoptosis related to oxidative stress in human umbilical vein endothelial cells: the role of protein kinase $\mathrm{C}$ and $\mathrm{NAD}(\mathrm{P}) \mathrm{H}$-oxidase activation. Diabetes 52:2795-2804

39. Weibel ER (1969) Stereological principles for morphometry in electron microscopic cytology. Int Rev Cytol 26:235-302
40. Duchen MR, Smith PA, and Ashcroft FM (1993) Substratedependent changes in mitochondrial function, intracellular free calcium concentration and membrane channels in pancreatic $\beta$ cells. Biochem J 294:35-42

41. Krauss S, Zhang CY, Scorrano L et al (2003) Superoxidemediated activation of uncoupling protein 2 causes pancreatic beta cell dysfunction. J Clin Invest 112:1831-1842

42. Brownlee M (2003) A radical explanation for glucose-induced beta cell dysfunction. J Clin Invest 112:1788-1790

43. Polonsky KS, Semenkovich CF (2001) The pancreatic beta cell heats up: UCP2 and insulin secretion in diabetes. Cell 105:705707

44. Joseph JW, Koshkin V, Zhang CY (2002) Uncoupling protein 2 knockout mice have enhanced insulin secretory capacity after a high-fat diet. Diabetes 51:3211-3219

45. Chan CB, MacDonald PE, Saleh MC, Johns DC, Marban E, Wheeler MB (1999) Overexpression of uncoupling protein 2 inhibits glucose-stimulated insulin secretion from rat islets. Diabetes 48:1482-1486

46. Patane G, Anello M, Piro S, Vigneri R, Purrello F, Rabuazzo AM (2002) Role of ATP production and uncoupling protein-2 in the insulin secretory defect induced by chronic exposure to high glucose or free fatty acids and effects of peroxisome proliferator-activated receptor-gamma inhibition. Diabetes 51:2749-2756

47. Laybutt DR, Sharma A, Sgroi DC, Gaudet J, Bonner-Weir S, Weir GC (2002) Genetic regulation of metabolic pathways in beta-cells disrupted by hyperglycemia. J Biol Chem 277:1091210921

48. Brown JE, Thomas S, Digby JE, Dunmore SJ (2002) Glucose induces and leptin decreases expression of uncoupling protein2 mRNA in human islets. FEBS Lett 27:189-192

49. Medvedev AV, Robidoux J, Bai X et al (2002) Regulation of the uncoupling protein-2 gene in INS-1 beta-cells by oleic acid. J Biol Chem 277:42639-42644

50. Lameloise N, Muzzin P, Prentki M, Assimacopoulos-Jeannet F (2001) Uncoupling protein 2: a possible link between fatty acid excess and impaired glucose-induced insulin secretion? Diabetes 50:803-809

51. Wang MY, Shimabukuro M, Lee Y et al (1999) Adenovirusmediated overexpression of uncoupling protein-2 in pancreatic islets of Zucker diabetic rats increases oxidative activity and improves beta-cell function. Diabetes 48:1020-1025

52. Wakabayashi T (2002) Megamitochondria formation-physiology and pathology. J Cell Mol Med 6:497-538

53. Wakabayashi T, Karbowski M (2001) Structural changes of mitochondria related to apoptosis. Biol Signals Recept 10:2656

54. Karbowski M, Kurono C, Wozniak M et al (1999) Free radicalinduced megamitochondria formation and apoptosis. Free Radic Biol Med 26:396-409

55. Vincent AM, Brownlee M, Russell JW (2002) Oxidative stress and programmed cell death in diabetic neuropathy. Ann NY Acad Sci 959:368-383

56. Pai GM, Slavin BG, Tung P (1993) Morphologic basis for loss of regulated insulin secretion by isolated rat pancreatic islets. Anat Rec 237:498-505

57. Marselli L, Dotta F, Piro S et al (2001) Th2 cytokines have a partial, direct protective effect on the function and survival of isolated human islets exposed to combined proinflammatory and Th1 cytokines. J Clin Endocrinol Metab 86:4974-4978

58. Trincavelli ML, Marselli L, Falleni A et al (2002) Upregulation of mitochondrial peripheral benzodiazepine receptor expression by cytokine-induced damage of human pancreatic islets. J Cell Biochem 84:636-644 